\title{
Identification of Factors Affecting Decisions to Adopt Pesticides at Lowland Rice Farms in Indonesia
}

\author{
Effendy $^{1^{*}}$, Made Antara ${ }^{1}$, Muhardi $^{2}$, Marthen Robinson Pellokila ${ }^{3}$, Jangkung Handoyo Mulyo ${ }^{4}$ \\ ${ }^{1}$ Department of Agriculture Economics, Agriculture Faculty of Tadulako University, Palu 94118, Indonesia \\ ${ }^{2}$ Department of Agrotechnology, Agriculture Faculty of Tadulako University, Palu 94118, Indonesia \\ ${ }^{3}$ Agribusiness Study Program, Agriculture Faculty of Nusa Cendana University, Kupang 85000, Indonesia \\ ${ }^{4}$ Department of Agricultural Socio-Economics, Gadjah Mada University, Yogjakarta 55281, Indonesia
}

\section{Corresponding Author Email: effendy_surentu@yahoo.com}

https://doi.org/10.18280/ijdne.160614

Received: 6 July 2021

Accepted: 8 December 2021

\section{Keywords:}

lowland rice farmers, pesticides, application

frequency, double-hurdle model

\begin{abstract}
Pesticides have been widely adopted in the farming industry to control weeds, pests, and diseases in order to minimize yield losses and maintain the quality of lowland rice products; however, farmers often over-apply pesticides. This study analyzed key factors that affected the decision of lowland rice farmers in adopting pesticides and the frequency of pesticide application. A double-hurdle model was used to estimate the factors that affected the decisions of farmers to adopt pesticides and determine the frequency of pesticide application. These results demonstrate that the adoption of pesticides was high $(86 \%)$ at lowland rice farms in the study area. Lowland rice farmers were found to apply pesticides an average of eight times. Gender, age, education level, access to extension, farming experience, and access to credit significantly affected the decisions of farmers to adopt pesticides in controlling weeds, pests, and diseases at lowland rice farms. The independent variable also significantly affected the frequency of pesticide application. Towards the goal, government and non-government organizations had to increase human resources through education, agricultural extension services to young farmers had to be improved. Specifically, extension material was provided on environmentally-friendly methods of controlling weeds, pests, and diseases and other alternatives to reduce the use of pesticides at lowland rice farms.
\end{abstract}

\section{INTRODUCTION}

The output of lowland rice farming is essential to the Indonesian economy, especially as a source of employment and income for $\sim 21$ million agricultural households [1]. Rice is a staple food for $\sim 95$ percent of Indonesia's population. In addition, rice is a strategic political commodity; domestic rice production is a benchmark of food availability for Indonesia [1].

Apart from the importance of rice economically, politically, and food availability, its production in Indonesia has been threatened by pests and diseases. This situation has resulted in a decrease in rice production, with a negative impact on the economy of farmers. Pesticides are modern agricultural technologies that have been widely adopted by rice farmers in Indonesia to control pests and diseases in order to reduce yield losses.

The use of pesticides in lowland rice farming in Indonesia has raised many concerns about residues in rice, as well as other potential hazards to humans and the environment [2-4]. Farmers often did not use pesticides as recommended by the government; they often used pesticides excessively and did not follow the rules regarding the use of chemicals $[5,6]$.

As a result, farmers might have been exposed to chemicals that were harmful to their health. Exposure to pesticides can have long-term effects on thyroid function, and lead to birth defects, as well so disorders of the reproductive, immune, and endocrine system, skin problems, behavior changes, and cancer [7-9]. Short-term effects that arose from pesticide exposure include headaches, skin irritation, vision disorders, respiratory problems, dizziness, and nausea $[9,10]$.

While previous studies have revealed the effects of pesticide exposure, the use of pesticides remained still high among lowland rice farmers in Indonesia. A question that arose was what influenced farmers' decisions to adopt pesticides? Clear answers to these questions would enable stakeholders such as the Ministry of Agriculture to identify specific issues that affected the use of pesticides in order to suggest the appropriate policies to decrease or increase the use of pesticides.

Pesticide adoption was affected by several factors, such as weed types, pests and diseases, and to reduce harvest risk [11, 12]. The results of the research [13-17] showed that farmers' age, education, farming experience, extension contacts, credit, and real income were factors that affected the technology adoption process.

This research aimed to analyze the factors that affected farmers' decisions to adopt pesticides in Indonesia. Previous studies $[2,4,10,18]$ showed the factors that affected pesticide adoption differed between regions. This was because of differences in climate, types of weeds, pests and diseases, natural resources, agricultural technology, and socioeconomic conditions. This research also increased knowledge about the factors that affected pesticide adoption by focusing on the 
frequency of its application. This research used a multiple barrier approach that allowed estimation of the factors that affected pesticide adoption and its application frequency.

\section{MATERIALS AND METHODS}

\subsection{Study areas and sample size}

This research was conducted in Central Sulawesi. Central Sulawesi is the second rice barn after South Sulawesi on the Sulawesi Island. Central Sulawesi is located between $2^{\circ} 22^{\prime}$ North Latitude and $3^{\circ} 48^{\prime}$ South Latitude and between $119^{\circ}$ $22^{\prime}-124^{\circ} 22^{\prime}$ East Longitude, with an area of $61,841.29 \mathrm{~km}^{2}$ [19]. The equator crossing the northern peninsula in Central Sulawesi makes the climate of this region tropical. The rainy season in Central Sulawesi is between April and September; the dry season is between October and March. Average rainfall ranges from 800 to $3,000 \mathrm{~mm}$ per year, among the lowest in Indonesia. Temperatures range from 25 to $31^{\circ} \mathrm{C}$ for plains and beaches with humidity levels range from 71 to $76 \%$. In mountainous regions temperatures can reach 16 to $22^{\circ} \mathrm{C}$. The most wind direction during 2018 was from the North, with an average speed of 4.5 knots.

The Parigi Moutong and Sigi distrcites were selected as both have the widest area of lowland rice harvesting, $21.31 \%$ $(43,294 \mathrm{ha})$ and $15.30 \%$ (31,079 ha), respectively. Parigi Moutong and Sigi have a productivity of 5.87 tons/ha and 4.37 tons/ha, respectively. Within each, three villages were randomly selected to be surveyed (Table 1).

Table 1. Study areas

\begin{tabular}{ccc}
\hline District & Villages & Sample size (HH) \\
\hline Sigi & Ranteleda & 56 \\
& Tanah Harapan & 44 \\
Parigi Moutong & Tongoa & 52 \\
& Balinggi & 65 \\
& Astina & 52 \\
& Nambaru & 60 \\
\hline \multicolumn{3}{c}{ Total } \\
Note: household head (HH) \\
Source: processed data result of 2021
\end{tabular}

This study used 329 randomly-selected lowland rice farms. Data on production input, price of production input, amount of output, price of output, and information on household characteristics of lowland rice farmers such as gender, age, level of education, access to extension, farming experience, access to credit were collected from March to May, 2021.

\subsection{Analytical framework}

This study analyzed the decision of lowland rice farmers to use pesticides. Farmers were faced with a decision as to how many times pesticides were applied to the lowland rice crops. Thus, a double-hurdle model was used to estimate that thing. The double-hurdle model was originally formulated by Cragg [20] and loosened the limitations of the Tobit model by assuming two hurdles in the process of using pesticides in lowland rice farming. The first obstacle related to farmers' decisions to adopt pesticides and the second related to their decision about the frequency of pesticide application. As per Martínez-Espiñeira [21], Aristei and Pieroni [22], and Garc'ia [23], the double-hurdle model can be written as:

$$
y_{i 1}^{*}=\alpha x_{i}+\varepsilon_{1}
$$

Decision to use pesticides

$$
y_{i 2}^{*}=\beta x_{i}+\varepsilon_{2}
$$

Decision on the frequency of pesticides application

$$
\begin{gathered}
y_{i}=\beta x_{i}+\varepsilon_{2} \\
\text { if } y_{i 1}^{*}>0 \text { and } y_{i 2}^{*}>0 \\
y_{i}=0 \\
\text { otherwise }
\end{gathered}
$$

where, $y_{i 1}^{*}$, is the latent variable describing the probability of farmer $i$ to adopt pesticides ( 1 if adopt pesticides and 0 if not); $y_{i 2}^{*}$ is a latent variable representing the frequency of pesticide application for farmers that adopt it; $x_{i}$ is a vector of independent variables; $\beta$ is the parameter vector to be estimated; and $\varepsilon$ are errors terms, which are assumed to be independent and normally distributed $(\varepsilon \sim N(0,1)$ and $\left.\varepsilon \sim N\left(0, \sigma^{2}\right)\right)$.

\subsection{Empirical model}

The empirical model of this study is as follows:

For decision to adopt pesticides:

$$
\begin{gathered}
y_{i 1}^{*}=\alpha_{0}+\alpha_{1} \mathrm{X}_{1}+\alpha_{2} \mathrm{X}_{2}+\alpha_{3} \mathrm{X}_{3}+\alpha_{4} \mathrm{X}_{4}+\alpha_{5} \mathrm{X}_{5}+\alpha_{6} \mathrm{X}_{6}+ \\
\alpha_{7} \mathrm{X}_{7}+\varepsilon_{1}
\end{gathered}
$$

For decision on the frequency of pesticides application:

$$
\begin{gathered}
y_{i 2}^{*}=\beta_{0}+\beta_{1} x_{1}+\beta_{2} x_{2}+\beta_{3} x_{3}+\beta_{4} x_{4}+\beta_{5} x_{5}+\beta_{6} x_{6}+ \\
\beta_{7} x_{7}+\varepsilon_{2}
\end{gathered}
$$

$y_{i 1}^{*}=$ the decision to adopt pesticides $(1=$ adopt pesticides and $0=$ otherwise), $y_{i 2}^{*}=$ frequency of pesticides application, $\alpha_{0}$ and $\beta_{0}=$ intercept, $\alpha_{1-7}$ and $\beta_{1-7}=$ the coefficient of the independent variable, $\mathrm{x}_{1}-\mathrm{x}_{7}=$ independent variable, $\varepsilon=$ error term. The independent variables are defined as follows:

$\mathrm{x}_{1}=$ the gender of household head $(\mathrm{HH})$,

$\mathrm{x}_{2}=$ age of $\mathrm{HH}$,

$\mathrm{x}_{3}=$ education level of $\mathrm{HH}$,

$\mathrm{x}_{4}=$ access to extension of $\mathrm{HH}$,

$\mathrm{x}_{5}=$ farming experience of $\mathrm{HH}$,

$\mathrm{x}_{6}=$ access to credit of $\mathrm{HH}$,

$\mathrm{x}_{7}=$ land area of lowland rice.

$\mathrm{x}_{1}-\mathrm{x}_{7}$ are included as independent variables based on the results of previous studies [4, 18, 24-34] which are described in subchapter 2.4 .

\subsection{Explanation and measurement of independent variables}

Gender plays an important role in the efficiency of the agriculture field [24, 25]. According to Goldner et al. [26] females are more susceptible to pesticide exposure; this caused males to use pesticides more frequently and at higher application rates than female farmers. In this study, laborers in lowland rice farming were male and female so that the gender was included as a dummy variable $(1=$ male and $0=$ other $)$. Age had a negative effect on the adoption of agricultural technology; young farmers were more likely to adopt new technology than older farmers $[4,27]$. The results show that with increasing age a farmer was less likely to use pesticides 
$[28,29]$. The age of the household head was measured in years.

Level of education might affect farmers in deciding to use pesticides and adopting new technologies [30, 31]. Education in this study was measured on a Liker scale $(1=$ not graduating from elementary school, 2 = graduating from elementary school, 3 = graduating from junior high school, 4 = graduating from senior high school, and 5 = graduating from college).

Extension agents could introduce new technologies such as use of environmentally-friendly pesticides to farmers so farmers tended to adopt them [18]. They could also provide guidance as to the frequency of pesticides application to effectively control pests $[32,33]$. Farmers with more access to the agricultural extension might use pesticides more effectively. Access to agricultural extension was measured by the presence number of household head measured by number.

Farmers with experience in agriculture would use technology effectively in increasing productivity [27, 34]. They tended to use pesticides that were environmentally friendly and reduce the application frequency of chemical pesticides [35]. The experience of lowland rice farming was stated in year.

Credit access could affect farming efficiency because farmers' credit could provide production input [25]. Credit access has given farmers the money to buy pesticides regardless of price $[29,36]$. Credit tended to lead to farmers buying more pesticides, which might affect the adoption of pesticides and frequency of application [36].

Land area is a continuous variable; with increasing land area there is a tendency for the adoption of pesticides to increase. Farming with large land areas tends to use more resources for crop production [37]. Land area in this study is expressed in hectares.

\section{RESULTS AND DISCUSSION}

\subsection{The statistical description of the study variable}

The statistics summary of this study variable is presented in Table 2.

Table 2 shows that study variables had a smaller standard deviation value from the average value, suggesting that populations tended to be homogeneous and the data distributed normal, such that data analyses were more suitable to a parametric approach (double-hurdle model). The average of land area of lowland rice farming is 1.93 ha per farming. The main costs in lowland rice farming were seeds, chemical fertilizers, labors, pesticides, and post-harvest chargers. $86 \%$ of farmers adopted pesticides; the frequency of application ranged from 3 to 12 times with an average of 8 . Lowland rice farming managers were mostly male (74\%); this suggests that males had greater access to agricultural land than females. On average, lowland rice farmers were age 44; this indicated a good quality of work in lowland rice production because young farmers were more energetic and tended to adopt new technologies. The education level of respondents was elementary school and access to extension was an average of 6 times per year; this tended to make farmers hesitant to adopt new technology. The average length of farming experience was 15 years; this meant that people involved in the production of lowland rice were experienced. Access to credit for lowland farmers was $55 \%$, which allowed farmers to prepare pesticides to control pests and diseases.
Table 2. Statistics summary of study variable

\begin{tabular}{cccc}
\hline Variables & Units & Mean & Std. Dev. \\
\hline Use of pesticides & dummy & 0.86 & 0.35 \\
Application Frequency & number & 7.64 & 2.68 \\
Gender & dummy & 0.74 & 0.44 \\
Age & year & 44.49 & 9.83 \\
Education & Likert scale & 1.91 & 0.76 \\
Access to extension & number & 6.10 & 2.89 \\
Farming experience & year & 14.67 & 5.06 \\
Access to credit & dummy & 0.57 & 0.50 \\
Land area & ha/farm & 1.93 & 0.61 \\
\multicolumn{4}{c}{ Source: processed data result of 2021 } \\
\multicolumn{4}{c}{}
\end{tabular}

\subsection{Types and sources of pesticides}

Most ( $86 \%$ ) of the respondents adopted pesticides to control weeds, pests, and diseases at lowland rice farms; $14 \%$ did not use them. Lowland rice farmers (86\%) adopted approved and recommended pesticides in Indonesia to control weeds, pests, and diseases. Table 3 presents a list of herbicides, fungicides, and insecticides used by respondent farmers.

Lowland rice farmers obtained pesticides from agrochemical shops in villages, sub-districts, districts, and provinces. Table 3 shows that farmers use three types of pesticides, namely insecticides, herbicides, and fungicides. Insecticides were used to control insects, herbicides to control weeds, and fungicides to control fungi [38]. The use of pesticides was very important for farmers to control pests and diseases so that their use has increased over time [39].

\subsection{Factors that affected the adoption and frequency of pesticides application}

Results of the statistical analysis of double hurdle model against the factors that affected the adoption and frequency of pesticides application at lowland rice are presented in Table 4.

Table 4 shows that six independent variables had a significant effect on the decisions of farmers in the adoption and frequency of pesticide applications, except for lowland rice land area. Gender was positively correlated with pesticide adoption and statistically significant at $\alpha 5 \%$, which means that male farmers were more likely to adopt pesticides. This might be because male farmers adopted new technologies more quickly, or because women had a higher health risk when they came into contact with pesticides [26, 40,41]. Gender was also positively correlated with the frequency of pesticide application and was statistically significant at $\alpha 1 \%$, implying that male farmers were more likely to apply pesticides repeatedly. This could occur because male farmers played a greater role in agricultural land [25], so that they often saw pests and diseases in lowland rice.

Age had a positive and statistically significant effect as $\alpha$ $1 \%$ on decisions of farmers in adoption and frequency of pesticide application in lowland rice. This shows that older farmers often applied pesticides to lowland rice attacked by pests and diseases. These results are consistent with those of Denkyirah [29], which stated that older farmers are more likely to use pesticides than young farmers. Older farmers in the study area have been using pesticides for years, so they paid more attention to the impact of pesticides on lowland rice rather than health, in contrast to younger farmers [42]. These results are consistent with the findings of Effendy [27], which state that older farmers who were more experienced in farming and they were more worried about pests and diseases, so they used pesticides more often. 
Table 3. Herbicides, fungicides, and insecticides used by respondent farmers

\begin{tabular}{cccc}
\hline No. & Trade name & Active ingredient & Main use \\
\hline 1 & Basagran & Bentazon, MCPA & Herbicide \\
2 & Roundup Powermax & Glifosat & Herbicide \\
3 & Tetris & Profoxydim & Herbicide \\
4 & Ally & metil metsulfuron & Herbicide \\
5 & Tabas & Natrium bispribak & Herbicide \\
6 & Abolisi & 2,4-D Dimetil Amina & Herbicide \\
7 & DMA & 2-4-D dimetil amina & Herbicide \\
8 & Clipper & Penoksulam & Herbicide \\
9 & Amistar Top & difenokonazol and azoksistrobin & Fungicide \\
10 & Filia & Propikonazol & Fungicide \\
11 & Antracol & Propineb & Fungicide \\
12 & Score & Difenokozanol & Fungicide \\
13 & Danvil & Heksakonazol & Fungicide \\
14 & Nativo & Tebukonazol, Trifloksistrobin & Fungicide \\
15 & Regent & Fipronil & Insecticide \\
16 & Virtako & Klorantraniliprol, tiametoksam & Insecticide \\
17 & Laser & Permethryn & Insecticide \\
18 & Fostin & klorpirifos & Insecticide \\
19 & Dangke & metomil & Insecticide \\
20 & Ares & nitenpyram & Insecticide \\
21 & Ayuna & Klorfluazuron & Insecticide \\
22 & Plenum & pimetrozin & Insecticide \\
\hline
\end{tabular}

Table 4. Double hurdle model estimation against the decision of farmers to adopt pesticides

\begin{tabular}{|c|c|c|c|c|c|c|}
\hline \multirow[t]{2}{*}{ Variables } & \multicolumn{3}{|c|}{$\begin{array}{c}\text { Probability of adopting } \\
\text { Pesticide (Hurdle 1) }\end{array}$} & \multicolumn{3}{|c|}{ Frequency of pesticides application (Hurdle 2} \\
\hline & Coefficient & Std. Err. & P value & Coefficient & Std. Err. & P value \\
\hline $\mathrm{X} 1$ & $0.657 * *$ & 0.287 & 0.022 & $0.871 * * *$ & 0.310 & 0.005 \\
\hline $\mathrm{X} 2$ & $0.095 * * *$ & 0.016 & 0.000 & $0.103 * * *$ & 0.034 & 0.002 \\
\hline X3 & $-0.515 * * *$ & 0.155 & 0.001 & $-0.583 * * *$ & 0.202 & 0.004 \\
\hline $\mathrm{X} 4$ & $-0.463 * * *$ & 0.045 & 0.000 & $-0.307 * * *$ & 0.055 & 0.000 \\
\hline $\mathrm{X} 5$ & $0.060^{*}$ & 0.031 & 0.054 & $-0.112 * *$ & 0.048 & 0.019 \\
\hline X6 & $1.547 * * *$ & 0.236 & 0.000 & $0.984 * * *$ & 0.328 & 0.003 \\
\hline X7 & $-0.069^{\mathrm{ns}}$ & 0.181 & 0.705 & $0.165^{\text {ns }}$ & 0.267 & 0.536 \\
\hline Constant & $4.469 * * *$ & 0.789 & 0.000 & $0.863^{\text {ns }}$ & 1.216 & 0.478 \\
\hline Sigma constant & & & & $0.596 * * *$ & 0.043 & 0.000 \\
\hline $\mathrm{Chi}^{2}$ & 387.000 & & & & & \\
\hline Log likelihood & -618.39831 & & & & & \\
\hline Prob $>\mathrm{chi}^{2}$ & 0.000 & & & & & \\
\hline $\mathrm{N}$ & 329 & & & 281 & & \\
\hline
\end{tabular}

Table 5. Harvest yield, income, and feasibility of lowland rice farming

\begin{tabular}{ccccccc}
\hline \multirow{2}{*}{ Household } & \multicolumn{2}{c}{ Rice (kg/ha) } & \multicolumn{2}{c}{ Income (IDR/ha) } & \multicolumn{2}{c}{ R/C } \\
\cline { 2 - 7 } & Mean & Std. Deviation & Mean & Std. Deviation & Mean & Std. Deviation \\
\hline Non-Adoption of Pesticides & $3,056^{\mathrm{a}}$ & 119 & $13,557,541^{\mathrm{a}}$ & $1,103,501$ & $2.09^{\mathrm{a}}$ & 0.10 \\
Adoption of Pesticide & $3,296^{\mathrm{b}}$ & 93 & $12,136,867^{\mathrm{b}}$ & $1,665,148$ & $1.78^{\mathrm{b}}$ & 0.18 \\
\hline \multicolumn{7}{c}{ Note: the different letters in one column means significantly different in $\alpha=5 \%$ two-tailed test. } \\
\hline \multicolumn{5}{c}{ Source: processed data result of 2021.}
\end{tabular}

Decisions to adopt and how frequently to apply pesticide application were negatively associated with farmer education level and statistically significant at $\alpha 1 \%$. This finding is in line with those of Anang and Amikuzuno [18], which indicated that education tended to reduce the probability of pesticide adoption in lowland rice crops. Farmers with higher education did not only think about the impact of pesticides on lowland rice but also the impact of pesticides on health. Farmers with higher education might choose other alternatives in controlling pests and diseases of lowland rice. However, these results are not consistent with the findings of Denkyirah [29] which stated that education had a positive effect on the frequency of pesticide application. Our findings show that education tended to reduce the frequency of pesticide application to lowland rice crops. Farmers who had higher education would consider the impact of pesticides on health so that they would use pesticides effectively and efficiently.

Access to extension services had a negative and statistically significant effect at $\alpha 1 \%$ on decisions of lowland rice farmers in the adoption and frequency of pesticide application. This suggests that access to agricultural extension services tended to reduce the probability of adoption and frequency of pesticide application. This agrees with the findings of Anang and Amikuzuno [18] and Denkyirah [29], which emphasize 
that access to extension services affected farmers to tend not to adopt pesticides to control pests and diseases. Denkyirah [29] also emphasize that access to extension services caused farmers to tend to reduce the frequency of pesticide application. The extension was an effective method to promote rational pesticide application [43]. This was because extension workers could introduce new technologies other than pesticides to farmers in controlling pests and diseases. Access to the extension would increase the adoption of a more effective technology [27]; extension services could therefore be used as an effective tool to reduce pesticide application among farmers.

Farming experience was positively correlated with pesticide adoption and significant at $\alpha 10 \%$; this means that higher farming experience tended to increase the probability of pesticide adoption. However, farming experience had a significant negative effect at $\alpha 10 \%$ on the frequency of pesticide application. This finding is in line with Denkyirah [29], which means that as farming experience increased, the frequency of pesticide application tended to decrease. This suggests that experienced farmers would be effective and efficient in using pesticides on lowland rice farms. In addition, experienced farmers did not apply pesticides excessively because they knew it tended to cause health and environmental hazards. According to Hashemi [42], farmers who experienced health problems due to the use of pesticides paid more attention to the impact of pesticides on health. Years of farming experience would increase the adoption of a more effective technology [27]. Many years of farming experience would ensure farmers had better skills in their fields and could access new information about available environmentallyfriendly technologies.

Access to credit had a positive correlation with the adoption and frequency of pesticide application and was significant at $\alpha$ $1 \%$; this means that access to credit tended to increase the probability for farmers to adopt pesticides in lowland rice. Farmers who got credit tended to buy production inputs for their farming needs $[25,36,44]$. Access to credit tended to increase the frequency of pesticide application in lowland rice farming. This occurred because farmers had more purchasing power [36]; however, it could be due to pests and diseases that developed in farming [10].

\subsection{Harvest yield and feasibility of lowland rice farming}

The average harvest yield, income, and $\mathrm{R} / \mathrm{C}$ of lowland rice farming are listed in Table 5.

Independent t-test analysis shows that the harvest yield, income, and $\mathrm{R} / \mathrm{C}$ of lowland rice farming were significantly different between farmers who adopted pesticides and those who did not. The harvest yield of lowland rice that used pesticides was significantly higher than the harvest yield of lowland rice that did not use pesticides. This implies that pesticides could reduce crop failure in lowland rice. In organic farming, harvest yields were generally lower than the harvest yield of inorganic farming. Klima and Labza [45] examined wheat harvest yields in both farming systems, harvest yields in the organic system were found to be lower by $12 \%$ compared to the inorganic system, but on the other hand, the product quality of the organic system was better. The income and feasibility of lowland rice farming that did not use pesticides were significantly higher than lowland rice farming that used pesticides. This implies that lowland rice farming that did not use pesticides had lower production costs. With reduced production costs, it would increase lowland rice farming income. Mustamin [46] shows that pesticides were one of the factors that had a positive and significant effect on the cost of lowland rice farming.

\section{CONCLUSION}

Most ( $86 \%$ of) farmers used pesticides to control weeds, pests, and diseases in lowland rice farms in Indonesia. The average frequency of pesticide application was 8 times per planting season. Independent variables including farmer gender, age, experience, education level, as well as access to extension and credit had a significant effect on the decision of farmers to adopt pesticides in controlling weeds, pests, and diseases. These variables also had a significant effect on the frequency of pesticide application in lowland rice farming.

\section{ACKNOWLEDGMENTS}

We would like to thank the Ministry of Research, Technology, and Higher Education of the Republic of Indonesia for providing funding for this study.

\section{REFERENCES}

[1] Satria, B., Harahap, E.M., Jamilah. (2017). Peningkatan produktivitas padi sawah (oryza sativa 1.) melalui penerapan beberapa jarak tanam dan sistem tanam. Jurnal Agroekoteknologi, 5(3): 629-637.

[2] Pimentel, D. (2005). Environmental and socio economic costs of the applications of pesticides primarily in the United States. Environ Dev Sustain, 7: 229-252. https://doi.org/10.1007/978-1-4020-8992-3_4

[3] Hou, B., Wu, L. (2010). Safety impact and farmer awareness of pesticide residues. Food Agric Immunol, 21(3):

191-200. https://doi.org/10.1080/09540105.2010.484858

[4] Adejumo, O.A., Ojoko, E.A., Yusuf, S.A. (2014). Factors influencing choice of pesticides used by grain farmers in Southwest Nigeria. J. Biol. Agric. Healthcare, 4(28): 31-38.

[5] Konradsen, F. (2007). Acute pesticide poisoning: A global public health problem. Dan Med Bull, 54(1): 5859.

[6] Sam, K.G., Andrade, H.H., Pradhan, L., Pradhan, A., Sones, S.J., Rao, P.G., Sudhakar, C. (2008). Effectiveness of an educational program to promote pesticide safety among pesticide handlers of South India. Int Arch Occup Environ Health, 81(6): 787-795. https://doi.org/10.1007/s00420-007-0263-3

[7] Mesnage, R., Clair, E., de Vendômois, J.S., Seralini, G.E. (2010). Two cases of birth defects overlapping StrattonParker syndrome after multiple pesticide exposure. Occup Environ Med, 67(5): 359. https://doi.org/10.1136/oem.2009.052969

[8] Cocco, P., Satta, G., Dubois, S., Pilleri, M., Zucca, M., Mannetje, A.M., Becker, N., Benavente, Y., Sanjose, S.D., Foretova, L., Staines, A., Maynadie, M., Nieters, A., Brennan, P., Miligi, L., Ennas, M.G., Boffetta, P. (2013). Lymphoma risk and occupational exposure to pesticides: results of the Epilymph study. Occup Environ Med, 70(2): 
91-98. https://doi.org/10.1136/oemed-2012-100845

[9] Gill, H.K., Garg, H. (2014). Pesticides: Environmental impacts and management strategies. In: Soloneski S (ed) Pesticides-toxic Aspects

$188-230$ https://doi.org/10.5772/57399

[10] Ntow, W.J., Gijzen, H.J., Kelderman, P., Drechsel, P. (2006). Farmer perceptions and pesticide use practices in vegetable production in Ghana. Pest Manag Sci., 62(4): 356-365. https://doi.org/10.1002/ps.1178

[11] Abdollahzadeh, G., Sharifzadeh, M.S. (2021). Predicting farmers' intention to use PPE for prevent pesticide adverse effects: An examination of the Health Belief Model (HBM). Journal of the Saudi Society of Agricultural Sciences, 20(1): 40-47. https://doi.org/10.1016/j.jssas.2020.11.001

[12] Sharifzadeh, M.S., Abdollahzadeh, G. (2021). The impact of different education strategies on rice farmers' knowledge, attitude and practice (KAP) about pesticide use. Journal of the Saudi Society of Agricultural Sciences, 20(5):

312-323 https://doi.org/10.1016/j.jssas.2021.03.003

[13] Moga, L.M., Constantin, D.L., Antohi, V.M. (2012). A regional approach of the information technology adoption in the Romanian Agricultural Farms. Informatica Economică, 16(4): 29-36.

[14] Nyanga, P.H. (2012). Factors influencing adoption and area under conservation agriculture: A mixed methods approach. Sustainable Agriculture Research, 1(2): 27-40. http://dx.doi.org/10.5539/sar.v1n2p27

[15] Paxton, K.W., Mishra, A.K., Chintawar, S., Roberts, R.K., Larson, J.A., English, B.C., Lambert, D.M., Marra, M.C., Larkin, S.L., Reeves, J.M., Martin, S.W. (2011). Intensity of precision agriculture technology adoption by cotton producers. Agricultural and Resource Economics Review, 40(1): 133-144 https://doi.org/10.1017/S1068280500004561

[16] Singha, A.K., Baruah, M.J., Bordoloi, R., Dutta, P., Saikia, U.S. (2012). Analysis on influencing factors of technology adoption of different land based enterprises of farmers under diversified farming system. Journal of Agricultural Science, 4(2): 139-146. http://dx.doi.org/10.5539/jas.v4n2p139

[17] Abdullah, F.A., Samah, B.A. (2013). Factors impinging farmers' use of agriculture technology. Asian Social Science, $9(3)$

$120-124$ http://dx.doi.org/10.5539/ass.v9n3p120

[18] Anang, B.T., Amikuzuno, J. (2015). Factors influencing pesticide use in smallholder rice production in Northern Ghana. Agriculture, Forestry and Fisheries, 4(2): 77-82. http://dx.doi.org/10.11648/j.aff.20150402.19

[19] BPS. (2019). Sulawesi Tengah Province in Figures. BPSStatistics of Sulawesi Tengah Province.

[20] Cragg, J.G. (1971). Some statistical models for limited dependent variables with application to the demand for durable goods. Econometrica, 39(5): 829-844.

[21] Martınez-Espineira, R. (2006). A Box-Cox DoubleHurdle model of wildlife valuation: The citizen's perspective. Ecological Economics, 58: 192-208. https://doi.org/10.1016/j.ecolecon.2005.07.006

[22] Aristei, D., Pieroni, L. (2008). A double-hurdle approach to modelling tobacco consumption in Italy. Applied Economics, 40(19): 2463-2476 https://doi.org/10.1080/00036840600970229

[23] Garc'ia, B. (2013). Implementation of a double-hurdle model. The Stata Journal, 13(4): 776-794. https://doi.org/10.1177/1536867X1301300406

[24] Bozoğlu, M., Ceyhan, V. (2007). Measuring the technical efficiency and exploring the inefficiency determinants of vegetable farms in Samsun province, Turkey. Agricultural Systems, 94: 649-656 https://doi.org/10.1016/j.agsy.2007.01.007

[25] Effendy, Pratama, M.F., Rauf, R.A., Antara, M., BasirCyio, M., Mahfudz, Muhardi. (2019). Factors influencing the efficiency of cocoa farms: A study to increase income in rural Indonesia. PLoS ONE, 14(4): e0214569. https://doi.org/10.1371/journal.pone.0214569

[26] Goldner, W.S., Sandler, D.P., Yu, F., Hoppin, J.A., Kamel, F., LeVan, T.D. (2010). Pesticide use and thyroid disease among women in the agricultural health study. Am J Epidemiol., 171(4): 455-464. https://doi.org/10.1093/aje/kwp404

[27] Effendy, Nuhfil, H., Budi, S., Muhaimin, A.W. (2013). Effect characteristics of farmers on the level of technology adoption side-grafting in cocoa farming at Sigi Regency-Indonesia. Journal of Agricultural Science, 5(12): 154-160. https://doi.org/10.5539/jas.v5n12p72

[28] Baral, K., Roy, B.C., Rahim, K.M.B., Chatterjee, H., Mondal, P., Mondal, D., Ghosh, D., Talekar, N.S. (2006). Socio-economic parameters of pesticide use and assessment of impact of an IPM strategy for the control of eggplant fruit and shoot borer in West Bengal, India. Technical Bulletin No. 37. AVRDC publication number 06-673. AVRDC - The World Vegetable Center, Shanhua, Taiwan

[29] Denkyirah, E.K., Okoffo, E.D., Adu, D.T., Aziz, A.A., Ofori, A., Denkyirah, E.K. (2016). Modeling Ghanaian cocoa farmers' decision to use pesticide and frequency of application: The case of Brong Ahafo Region. SpringerPlus, 5(1): 1113. https://doi.org/10.1186/s40064-016-2779-z

[30] Enete, A.A., Igbokwe, E.M. (2009). Cassava market participation decisions of producing households in Africa Tropicultura, 27: 129-136.

[31] Martey, E., Wiredu, A.N., Asante, B.O., Kwame Annin, K., Dogbe, W., Attoh, C., Al-Hassan, R.M. (2013). Factors influencing participation in rice development projects: The case of smallholder rice farmers in Northern Ghana. International Journal of Development and Economic Sustainability, 1(2): 13-27.

[32] Tiamiyu, S.A., Akintola, J.O., Rahji, M.A.Y. (2009). Technology adoption and productivity difference among growers of new rice for Africa in Savanna Zone of Nigeria. Tropicultura, 27(4): 193-197.

[33] Omolehin, R.A., Ogunfiditimi, T.O., Adeniji, O.B. (2007). Factors influencing the adoption of chemical pest control in cowpea production among rural farmers in Makarfi Local Government area of Kaduna State, Nigeria. International Journal of Agricultural Research, 2: 920-928. https://dx.doi.org/10.3923/ijar.2007.920.928

[34] Idrisa, Y.L., Ogunbameru, B.O., Madukwe, M.C. (2012). Logit and tobit analyses of the determinants of likelihood of adoption and extent of adoption of improved soybean seed in Borno State, Nigeria. Greener J. Agric. Sci., 2(2): 37-45.

[35] Yasin, G., Aslam, M., Parvez, I., Naz, S. (2003). Socioeconomic correlates of pesticide usage: the case of citrus farmers. J Res Sci., 14(1): 43-48.

[36] Abu, G.A., Taangahar, T.E., Ekpebu, I.D. (2011). 
Proximate determinants of farmers WTP (willingness to pay) for soil management information service in Benue State, Nigeria. African Journal of Agricultural Research, 6(17): 4057-4064. https://doi.org/10.5897/AJAR11.326

[37] Zarafshani, K., Ghasemi, S., Houshyar, E., Ghanbari, R., Van Passel, S., Azadi, H. (2017). Canola adoption enhancement in western Iran. J. Agr. Sci. Tech., 19(1): 47-58. https://jast.modares.ac.ir/article-23-11474en.html.

[38] Ntow, WJ. (2004). Organochlorine pesticides in water, sediments, crops and human fluids in a farming community in Ghana. Journal of Archives of Environmental Contamination and Toxicology, 40(4): 557-563. https://doi.org/10.1007/s002440010210

[39] Alavanja, M.C.R., Ross, M.K., Bonner, M.R. (2013). Increased cancer burden among pesticide applicators and others due to pesticide exposure. CA Cancer J Clin., 63(2): 120-142. https://doi.org/10.3322/caac.21170

[40] Nkamleu, G.B., Adesina, A.A. (2000). Determinants of chemical input use in peri-urban lowland systems: bivariate probit analysis in Cameroon. Agric Syst., 63(2): 111-121. 521X(99)00074-8 https://doi.org/10.1016/S0308-

[41] Engel, L.S., Hill, D.A., Hoppin, J.A., Lubin, J.H., Lynch, C.F., Pierce, J., Samanic, C., Sandler, D.P., Blair, A., Alavanja, M.C. (2005). Pesticide use and breast cancer risk among farmers' wives in the Agricultural Health
Study. Am J Epidemiol, 161(2): 121-135. https://doi.org/10.1093/aje/kwi022

[42] Hashemi, S.M., Rostami, R., Hashemi, M.K., Damalas, C.A. (2012). Pesticide use and risk perceptions among farmers in southwest Iran. Hum Ecol Risk Assess, 18(2): 456-470. https://doi.org/10.1080/10807039.2012.652472

[43] Hashemi, S.M., Hosseini, S.M., Damalas, C.A. (2009). Farmers' competence and training needs on pest management practices: Participation in extension workshops. Crop Prot, 28(11): 934-939. https://doi.org/10.1016/j.cropro.2009.07.007

[44] Adepoju, A.O., Olaseni, O.C. (2021). Are yam farmers aware and willing to adopt the aeroponics farming system in Oyo State, Nigeria?. AGRIS on-line Papers in Economics and Informatics, 13(1): 3-13. https://doi.org/10.7160/aol.2021.130101

[45] Klima, K., Labza, T. (2010). Yielding and economic efficiency of oats crop cultivated using pure and mixed sowing stands in organic and conventional farming systems. Zywnosc-Nauka Technologia Jakosc, 17: 141147. http://dx.doi.org/10.15193/zntj/2010/70/141-147

[46] Mustamin, S.W. (2018). Faktor- faktor yang memengaruhi biaya usahatani padi. Jurnal Hukum $\begin{array}{lll}\text { Ekonomi } & \text { Syariah, } & 2(2) \text { : }\end{array}$ https://doi.org/10.26618/j-hes.v2i2.1621 